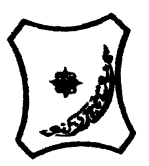

Bayero Journal of Pure and Applied Sciences, 12(1): 344 - 351

ISSN $2006-6996$

\title{
HEAVY METALS ANALYSIS AND TOXICITY EVALUATION OF SOME TEXTILE AND DYEING EFFLUENTS IN KANO, NIGERIA USING Allium cepa BIOASSAY
}

\author{
1*Abdullahi, U.A. and ${ }^{2}$ Ibrahim, S. \\ ${ }^{1,2}$ Department of Biological Science, Bayero University, Kano, P.M.B 3011, Kano State, Nigeria. \\ ${ }^{1 *}$ Corresponding Author: abdullahiubaahmed@gmail.com, auahmed.bio@buk.edu.ng GSM:
} $\underline{08068200148}$

ABSTRACT

Insufficiencies in dyeing and textile processing coupled with incomplete sewage treatment system lead to indiscriminate discharge of large amount of dyestuff into water bodies mostly used for irrigation and fishing. These wastes are potentially mutagenic and some are even carcinogenic. In this research, cytotoxicity of three industrial effluents viz; African Textile Manufacturer (ATM), Kofar Naisa and Kofar Mata dyeing centres were evaluated using Allium cepa bioassay. The concentrations of some heavy metals $(\mathrm{Cr}, \mathrm{Cd}$, $\mathrm{Zn}, \mathrm{Fe}, \mathrm{Cu}, \mathrm{Co}, \mathrm{Pb}, \mathrm{Mn}$ and $\mathrm{Ni}$ ) were also determined. Three sets of small onion bulbs were cultivated in 25\%, 50\% $75 \%$ and $100 \%$ effluent concentrations (v/v) and a control for each site. Root tips from each bulb were harvested and processed for cytological studies using squashing technique. After 48hrs of exposure, cytotoxic effects of the effluents on root tips (compared to control) showed root growth retardation which was more apparent at higher concentrations. This indicated that, the root growth inhibition was concentration dependent. Number of dividing cells observed and the Mitotic Index (MI) were also concentration dependent. There were decrease in number of dividing cells and $M I$ with increase in concentration of the treatment. The effective concentrations that caused $50 \%$ effect $\left(E C_{50}\right)$ was $95 \%$ for ATM and $K /$ Naisa dyeing points while it was $100 \%$ in $\mathrm{K} / \mathrm{mata}$ dyeing point. Diverse structural aberrations and abnormalities were observed ranging from chromosomal bridge, which was apparent even at low concentrations of the treatment to cytokinesis failure, Micronucleus (MN) and nuclear buds or vacuolated nuclei. Analysis of Variance (ANOVA) showed no significant difference $(P>0.05)$ in mean concentrations of $\mathrm{Cr}, \mathrm{Fe}, \mathrm{Cu}$ and Mn for K/Naisa and K/Mata dyeing centres, but there was statistical difference $(P<0.05)$ for these parameters in ATM. Likewise, there was significant difference $(P<0.05)$ in the root growth of $A$. cepa exposed to different concentrations of the effluent in ATM and $K / N a i s a$ sites but no statistical difference existed in root growth of $A$. cepa exposed to $K /$ Mata effluents.

Keywords: Allium cepa, Bioassay, Effluents, Cytotoxicity, Mitotic Index

INTRODUCTION

Environmental pollution is the second main constrain dooming the progress of developing countries apart from poverty and exponential growth in population (Grover and Kaur, 1999; Olusegun et al., 2010). According to Chan et al. (2003); Lah et al. (2004) and Smolder et al. (2004), industrial effluents are the main sources of direct and often continuous input of pollutants and toxicants into aquatic ecosystem causing long term implications onto the ecosystem functioning. Among these are textiles and dyeing industries. Effluents from textiles/dyeing industry act as the most important cause of environmental pollution, because the products are diverse in chemical composition (Ali et al., 2008). Insufficiencies in dyeing during textile processing always results in large amount of dyestuff being directly lost to the wastewater, which unavoidably find its ways into water bodies mostly used for irrigation and fishing (McMullan et al., 2007). These dyes undergo chemical changes under certain environmental conditions and the transformed products may even be more toxic and carcinogenic than the parent molecules (Weber and Adams, 1995; Ratna and Padhi, 2012). The effluents from textile/dyeing industries thus carry a large number of dyes and other additives which are difficult to remove in conventional water treatment procedures and can therefore be transported easily to the water bodies especially because they are designed to have high water solubility and can undergo degradation to form products that are highly toxic and carcinogenic (Rindle and Troll, 1975). The complexity of industrial effluents makes it impossible to carry out hazard assessment study based on physical and chemical analysis only. 
Special Conference Edition, November, 2019

Thus, in search of a test systems which can be combined with chemical analysis to provide a scientific data that will be useful as the basis for regulating the discharge of potentially hazardous substances into the environment and as well serve as a suitable method for toxicity evaluation, Devis and Ford (1992), Matcalf and Eddy (2003) proposed the use of biotoxicity test or bioassay, which involves the use of living organisms. Bioassay is typically conducted to measure the effect of substances (effluents in this case) on living organisms (in-vivo bioassay) or their tissues (in-vitro bioassay) in monitoring environmental pollution. True and Hayward (1990) reported that living organisms (plants or animals) serve as the most sensitive indicators of toxicity in an environment provided that they are judiciously monitored. Fiskesjo (1985; 1993) and Rank and Nielsen (1993; 1998) further considered the use of Allium cepa test as a standard method in environmental monitoring and toxicity screening of any wastewater. Odeigah et al. (1997) moreover, showed that the plant's root is the most useful tool in this test because the root tips are often the first predisposed to chemical contaminants in water and soil. The study therefore aimed at assessing the heavy metal concentrations as well as evaluating the toxicity effect of textile and dyeing effluent samples collected using Allium cepa bioassay.

\section{MATERIALS AND METHODS Study Area}

Kano, located at $11^{\circ} 59^{\prime} 18^{\prime \prime} \mathrm{N}$ and $08^{\circ} 32^{\prime} 06^{\prime}$ 'E about 418 metres above the sea level, occupies the central position in Northern Nigeria. It is one of the most populous and developed cities in Nigeria with dyeing and textile being among the dominating activities in the city (Akan et al., 2007). Within Kano metropolis, Textile

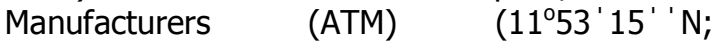
$\left.08^{\circ} 28^{\prime} 96^{\prime} ' \mathrm{E}\right)$, Kofar Naisa dyeing point $\left(11^{\circ} 58^{\prime} 95^{\prime}\right.$ ' $\mathrm{N}$; 0830'86' 'E) and Kofar Mata dyeing point $\left(11^{\circ} 39^{\prime} 95^{\prime}\right.$ ' $\mathrm{N}$; $08^{\circ} 31^{\prime} 41^{\prime}$ 'E) were selected for the study.

\section{Sample Collection}

The samples were collected in the early morning hours using 5 litre capacity jerry-can from each location as described by Maiti (2004). The samples were used for toxicity evaluation using Allium cepa chromosomal aberration bioassay and the heavy metals $(\mathrm{Cr}, \mathrm{Cd}, \mathrm{Zn}, \mathrm{Fe}, \mathrm{Cu}, \mathrm{Hg}$, $\mathrm{Pb}, \mathrm{Mn}$ and $\mathrm{Ni}$ ) using Atomic Absorption Spectrophotometry (AAS).

\section{Determination of Heavy Metals}

Heavy metals were determined by aspirating the samples using Atomic Absorption
Spectrophotometer (AAS) as described by Maiti, (2004) and APHA (2005). This was done after pre-digestion of the sample using single acid digestion method (Maiti, 2004 ; APHA, 2005).

Allium Chromosomal Bioassay of the Effluents

The design of the experiment was four groups of three onions. The groups are the different concentrations made (i.e. $25 \%, 50 \%, 75 \%$ and $100 \%$ ) while the 3 onions per each concentration are the replicates making a total of 36 onion bulbs.

The experiment was set-up allowing the rootlets to grow as described by Fikesjo (1985; 1993) and Rank and Nielson (1993). The onion bulbs of the size $7-12 \mathrm{~cm}$ in diameter were selected. The bases of the bulbs were gently scrapped to remove the older roots and expose the rootprimodia. The bulbs were placed in plastic cups containing distilled water. The set-up was then allowed to stay for 3 days for new roots to emerge. The root length (before and after the treatment) were determined using centimeter rule.

The onion bulbs were transferred to another plastic cups containing these different concentrations of effluent (as treatment) for 48 hours. The set-up was kept in the dark where by the concentration of the effluents was changed at 24 hour interval. The rootlets were harvested after 48 hours and immediately fixed in ethanol : glacial acetic acid $(3: 1, v / v)$ in a clean petri dish (Rank and Nielson, 1993; Abu and Ezeugwu, 2008; Olurunfemi et al., 2011). These were then hydrolyzed in $1 \mathrm{~N} \mathrm{HCl}$ at $60^{\circ} \mathrm{C}$ (using thermostat water bath) for 5 minutes after which the preparation was washed with distilled water. Two tips were squashed on each slide and stained with safranin stain for 2 minutes, the cover slip was carefully lowered on the preparation excluding the air bubbles. Several slides were prepared for each concentration and a control. The slides were then analyzed at $\times 10$, $\times 40$ and $\times 100$ magnification using Olympus electric microscope (XSZ-107BN- model).

The induced chromosomal aberrations were determined and Mitotic Index (MI) calculated as the number of dividing cells per 300 observed cells by 100 (Fiskesjo, 1985, 1997) as showm below:

$$
M I=\frac{\text { No of dividing cells }}{\text { Observed Cells }(300)} \times 100
$$

Percentage aberration was also calculated based on the total number of aberrant cells at each concentration of the effluent per total cells scored or examined (Bakare et al., 2000; Olorunfemi et al., 2011). 
100

$$
\% \text { aberration }=\frac{\text { Total } \text { No of aberrant cells }}{\text { Number of cells scored }} \times
$$

And $\mathrm{EC}_{50}$ (effective concentration that causes $50 \%$ effect on the experimental materials) was determined from the plot of root length as percentage of control against various sample concentrations otherwise called dose response curve (using Microsoft Excel computer program).

\section{RESULTS AND DISCUSSION}

The results of mean heavy metals for the three different sites were presented in Table 1 , and these were compared with the Federal Environmental Protection Agency Act (FEPA,
2002) and General Environmental Standard for Discharge of Effluents (Textiles/Dyestuffs and Dye Intermediate). Meanwhile, Table 2 shows the mean root length of Allium cepa before and after exposure to different concentrations of the effluents. Table 3 showed the numerical aberration (that includes number of dividing cells and mitotic index) which are among the effects observed in $A$. cepa on exposure to different concentrations of textile and dyeing effluents in different sites. and Table 4 shows the structural aberration observed in $A$. cepa root exposed to different concentrations of the effluent samples.

Table 1.: Mean Values for Heavy Metals of the Effluent Sample Collected and Analyzed Between September, 2016 and July, 2017

\begin{tabular}{|c|c|c|c|c|c|c|}
\hline \multicolumn{2}{|c|}{ Parameters $(\mathrm{mg} / \mathrm{L})$} & E1 & E2 & E3 & \multicolumn{2}{|c|}{ FEPA/GES } \\
\hline \multicolumn{2}{|c|}{$\mathrm{Cr}$} & $1.24 \pm 0.20^{\mathrm{a}}$ & $1.66 \pm 0.25^{b}$ & $1.82 \pm 0.19^{b}$ & \multicolumn{2}{|c|}{2.0} \\
\hline \multicolumn{2}{|c|}{$\mathrm{Cd}$} & $1.46 \pm 0.38$ & $1.47 \pm 0.30$ & $1.53 \pm 0.23$ & \multicolumn{2}{|l|}{1.0} \\
\hline \multicolumn{2}{|c|}{$\mathrm{Zn}$} & $2.43 \pm 1.23$ & $2.53 \pm 1.33$ & $3.19 \pm 1.31$ & \multicolumn{2}{|l|}{1.5} \\
\hline \multicolumn{2}{|c|}{$\mathrm{Fe}$} & $2.52 \pm 0.57^{\mathrm{a}}$ & $4.79 \pm 0.62^{b}$ & $4.41 \pm 0.49^{b}$ & \multicolumn{2}{|l|}{3.0} \\
\hline \multicolumn{2}{|c|}{$\mathrm{Cu}$} & $1.22 \pm 0.21^{\mathrm{a}}$ & $1.65 \pm 0.29^{b}$ & $1.71 \pm 0.55^{\mathrm{b}}$ & \multicolumn{2}{|l|}{3.0} \\
\hline \multicolumn{2}{|c|}{ Co } & $0.69 \pm 0.10^{\mathrm{a}}$ & $0.85 \pm 0.21^{b}$ & $0.72 \pm 0.20^{\mathrm{a}}$ & \multicolumn{2}{|l|}{0.0} \\
\hline \multicolumn{2}{|c|}{$\mathrm{Pb}$} & $0.51 \pm 0.10^{\mathrm{a}}$ & $0.61 \pm 0.15^{\mathrm{a}}$ & $0.78 \pm 0.14^{b}$ & \multicolumn{2}{|l|}{1.0} \\
\hline \multicolumn{2}{|c|}{$\mathrm{Mn}$} & $1.17 \pm 0.19^{\mathrm{a}}$ & $1.43 \pm 0.21^{b}$ & $1.38 \pm 0.32^{b}$ & \multicolumn{2}{|l|}{2.0} \\
\hline \multicolumn{2}{|c|}{$\mathrm{Ni}$} & $1.10 \pm 0.43$ & $1.24 \pm 0.58$ & $1.25 \pm 0.69$ & \multicolumn{2}{|l|}{3.0} \\
\hline \multirow{2}{*}{\multicolumn{7}{|c|}{ 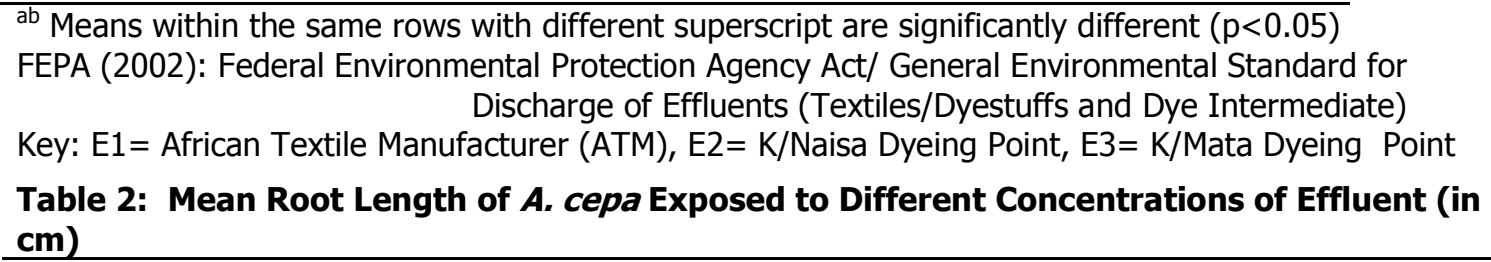 }} \\
\hline & & & & & & \\
\hline \multirow{2}{*}{$\begin{array}{l}\text { Conc. } \\
(\%)\end{array}$} & \multicolumn{2}{|c|}{ ATM } & \multicolumn{2}{|c|}{ K/Naisa } & \multicolumn{2}{|c|}{ K/Mata } \\
\hline & $\begin{array}{c}\text { MRLBT } \pm S \\
\text { D }\end{array}$ & $\begin{array}{c}\text { MRLAT } \pm S . \\
\text { D }\end{array}$ & $\begin{array}{c}\text { MRLBT } \pm S . \\
\text { D } \\
\end{array}$ & $\begin{array}{c}\text { MRLAT } \pm S . \\
\text { D }\end{array}$ & $\begin{array}{c}\text { MRLBT } \pm S . \\
\text { D }\end{array}$ & $\begin{array}{c}\text { MRLAT } \pm S \\
\text { D }\end{array}$ \\
\hline 25 & $6.9 \pm 0.45$ & $5.6 \pm 0.37$ & $6.9 \pm 0.35$ & $5.4 \pm 0.17$ & $6.0 \pm 1.70$ & $5.5 \pm 0.90$ \\
\hline 50 & $5.8 \pm 0.76$ & $5.1 \pm 0.53$ & $5.6 \pm 1.50$ & $4.7 \pm 0.76$ & $6.4 \pm 1.80$ & $6.0 \pm 1.91$ \\
\hline 75 & $5.9 \pm 0.67$ & $4.7 \pm 0.89$ & $6.9 \pm 0.99$ & $3.9 \pm 0.82$ & $6.2 \pm 0.57$ & $5.8 \pm 0.90$ \\
\hline 100 & $5.2 \pm 0.25$ & $4.2 \pm 0.49$ & $5.6 \pm 0.72$ & $2.6 \pm 0.31$ & $4.2 \pm 1.60$ & $4.1 \pm 1.50$ \\
\hline Contro & (5.7) & (7.2) & & & & \\
\hline
\end{tabular}

\footnotetext{
N.B: The Values are Mean \pm S.D of 3 replicates at each concentration

Key: MRLBT $=$ Mean Root Length Before Treatment

MRLAT = Mean Root Length After Treatment

S.D $=$ Standard Deviation
} 
Special Conference Edition, November, 2019

Table 3: Numerical Aberrations Observed in A. cepa Roots Exposed to Different

Concentrations of Textile and Dyeing Effluents for 48hours

\begin{tabular}{cccc}
\hline Samples & $\begin{array}{c}\text { Concentration } \\
(\mathbf{\%})\end{array}$ & $\begin{array}{c}\text { No. of Dividing } \\
\text { Cells }\end{array}$ & $\begin{array}{c}\text { Mitotic Index } \\
(\mathbf{\%})\end{array}$ \\
\hline E1 & 25 & 68 & 22.67 \\
& 50 & 53 & 17.67 \\
& 75 & 40 & 13.33 \\
E2 & 100 & 21 & 7.00 \\
& 25 & 70 & 23.33 \\
& 50 & 61 & 20.30 \\
E3 & 75 & 38 & 12.67 \\
& 100 & 15 & 5.00 \\
& 25 & 59 & 19.67 \\
& 50 & 46 & 15.33 \\
& 75 & 33 & 11.00 \\
& 100 & 18 & 6.00 \\
Control & $\mathbf{1 1 5}$ & $\mathbf{3 8 . 3 3}$ \\
\hline
\end{tabular}

N.B: 100 cells per onion were examined

Table 4: Structural Aberrations Observed in A. cepa Roots Exposed to Different Concentrations of Textile and Dyeing Effluents for 48hours

\begin{tabular}{cccccccccc}
\hline Samples & Conc.(\%) & Bridge & $\begin{array}{c}\text { Incomp. } \\
\text { Cytok. }\end{array}$ & MN & $\begin{array}{c}\text { Chr. } \\
\text { Adher. }\end{array}$ & $\begin{array}{c}\text { Nuclear } \\
\text { Buds }\end{array}$ & $\begin{array}{c}\text { Multi } \\
\text { polarity }\end{array}$ & Total & $\begin{array}{c}\text { \% } \\
\text { Aberr. }\end{array}$ \\
\hline E1 & 25 & 2 & 1 & 0 & 0 & 1 & 1 & 05 & 7.35 \\
& 50 & 3 & 1 & 1 & 1 & 1 & 1 & 08 & 15.09 \\
& 75 & 2 & 3 & 1 & 0 & 1 & 2 & 09 & 22.50 \\
E2 & 100 & 0 & 1 & 0 & 3 & 0 & 0 & 04 & 19.05 \\
& 25 & 1 & 1 & 0 & 0 & 1 & 0 & 03 & 4.29 \\
& 50 & 2 & 1 & 0 & 0 & 1 & 1 & 05 & 8.20 \\
& 75 & 2 & 4 & 1 & 1 & 1 & 1 & 10 & 26.32 \\
E3 & 100 & 0 & 0 & 0 & 2 & 0 & 0 & 02 & 13.33 \\
& 25 & 2 & 3 & 0 & 0 & 1 & 1 & 07 & 11.86 \\
& 50 & 1 & 1 & 1 & 0 & 2 & 0 & 05 & 10.87 \\
& 75 & 1 & 1 & 0 & 0 & 1 & 0 & 03 & 9.10 \\
& 100 & 0 & 0 & 0 & 1 & 0 & - & 01 & 5.56 \\
& Control & - & 1 & - & 2 & - & - & 03 & $\mathbf{2 . 6 1}$ \\
\hline
\end{tabular}

Key: $M N=$ Micro Nucleus, Chr. Adher. = Chromosome Adherence

Table5: $\mathrm{EC}_{50}$ and Regression Coefficient of Effluents at Different Sites Extracted from Dose-Response Curve

\begin{tabular}{|c|c|c|c|}
\hline Sites & $E C_{50}(\%)$ & $\mathbf{R}^{2}$ & $\mathbf{R}$ \\
\hline $\mathrm{E} 1$ & 95 & 0.8881 & 0.94 \\
\hline E2 & 95 & 0.9776 & 0.99 \\
\hline E3 & 100 & 0.4361 & 0.66 \\
\hline
\end{tabular}

\section{DISCUSSION}

Analytical results for heavy metals revealed that, the mean concentration of chromium $(\mathrm{Cr})$ in textile and dyeing effluents were 1.24, 1.66 and $1.82 \mathrm{mg} / \mathrm{l}$ for ATM (E1), K/Naisa (E2) and $\mathrm{K} /$ Mata (E3) textiles and dyeing points respectively. These mean values are lower than $2.38 \mathrm{mg} / \mathrm{l}$ of chromium metals recorded by Ugoji and Aboaba (2004) for textile industry effluent in Lagos metropolis, Nigeria. Chromium causes allergic reactions to the skin of exposed organism especially when discharged in wastewater into water-ways, streams and canals which humans use for their daily activities (ATSDR, 2005).

The concentrations of Cadmium (Cd) and Zinc (Zn) 1.46, 1.47, 1.53 and $2.43,2.53$ and 3.19 $\mathrm{mg} / \mathrm{l}$ for sites E1, E2 and E3 respectively, exceeded the recommended limit by FEPA (2002) (Table 1) for discharged effluents into the environment. These mean values for Cadmium are higher than $0.20 \mathrm{mg} / \mathrm{l}$ observed by Dubey et al. (2003) in local dye house effluent in New Delhi India. 


\section{Special Conference Edition, November, 2019}

Exposure to small concentration of cadmium for long time in food and water according to ATSDR (2005) leads to a build-up of cadmium in kidneys and results to possible kidney disease. Other potential long-term effects are lungs damage and fragile bones (ATSDR, 2005).

Likewise, concentration of iron (Fe) in E2 (4.79 $\mathrm{mg} / \mathrm{l})$ and E3 $(4.41 \mathrm{mg} / \mathrm{l})$ also exceeded $3.0 \mathrm{mg} / \mathrm{l}$ recommended limit for the discharge of effluent set by FEPA (2002). These values are greater than $2.14 \mathrm{mg} / \mathrm{l}$ the concentration of iron observed by Yusuff and Sonibare (2004). The mean concentrations of Copper however, were $1.22,1.65$ and $1.71 \mathrm{mg} / \mathrm{l}$ for the three sites under study; these values were lower than 5.14 $\mathrm{mg} / \mathrm{l}$ and $4.0 \mathrm{mg} / \mathrm{l}$ of copper reported by Aslam et al. (2004) and Yusuff and Sonibare (2004) in Kaduna, Nigeria. Copper is an essential element in mammalian nutrition as a component of metallo-enzymes in which it acts as an electron donor or acceptor (Deepali and Gangwar, 2010), but exposure to high level of copper can result in a number of adverse health effects such as diarrhea, stomach cramps, and nausea. (Bremner, 1998); chronic exposure may lead to liver damage and kidney disease. Moreover, the results revealed the concentration of Lead $(\mathrm{Pb})$ for the three sites as $0.51,0.61$ and $0.78 \mathrm{mg} / \mathrm{l}$ which are all below $1.0 \mathrm{mg} / \mathrm{l}$ standard limit for discharge of textile effluent by FEPA (2002), but research by Dubey et al. (2003) showed that long term exposure to lower concentration of lead may result in the accumulation which can cause serious effect to central nervous system and immune system particularly in children. Moreover, Dash et al. (1988) reported the range value of $0.29-0.43 \mathrm{mg} / \mathrm{l}$ of $\mathrm{Pb}$ and found the effect as clastogenic due to impairment of spindle function in $A$. cepa.

The present study also revealed that, the average concentrations for manganese were $1.17 \mathrm{mg} / \mathrm{l}$ for ATM, $1.43 \mathrm{mg} / \mathrm{l}$ for K/Naisa and $1.38 \mathrm{mg} / \mathrm{l}$ for $\mathrm{K} /$ Mata dyeing points. These values correspond with the average range of $1.15-1.65 \mathrm{mg} / \mathrm{l}$ for manganese observed by Yusuff and Sonibare (2004) in the effluent of textile industries in Nigeria. Although manganese is among the least toxic trace elements, but excessive discharge of effluents containing this amount may gradually accumulate and could provide source of continuing exposure that may lead to harmful effect in long term.

Statistically, no significant difference was observed between different sites ( E1, E2 and E3) for the mean concentration of $\mathrm{Cd}, \mathrm{Zn} \mathrm{Mn}$ and $\mathrm{Ni}(\mathrm{P}>0.05)$, but a significant difference $(\mathrm{P}<$ 0.05 ) was observed for the mean concentration of $\mathrm{Fe}, \mathrm{Cu}, \mathrm{Co}$ and $\mathrm{Pb}$ between different sites (Table 1).

The Allium cepa test have been used as a standard and quick method of detecting cytotoxic effect of chemicals and pollution levels in an environment ( Grant, 1982; Smaka-kinel et al., 1996). The results of $A$. cepa test indicated the presence of cytotoxic and mutagenic substances in the environment which represent direct or indirect risks to all living organisms by inhibiting the mitotic activities and interfering with growth and development of the test organisms.

The mean root length of $A$. cepa root before and after exposure to different effluent concentrations are presented in Table 2. The result revealed that, there is growth retardation in roots after been exposed to different effluent concentrations, and that, the root growth retardation is concentration dependent, thus, growth retardation was more apparent at higher concentration. That is, high growth rate was recorded in onion bulb exposed to lower concentration and vice versa. This agreed with the finding of Olorunfemi et al. (2011) where similar results were obtained in $A$. cepa root exposed to different concentrations of effluents from textile and rubber processing industries. Root growth retardation according to Odeigah et al. (1997) are indication of irreversible toxicity effect leading to possible cell death during prolong exposure, hence, roots decay were observed in higher $(75 \%$ and $100 \%)$ concentrations during the experiment. On comparing with control, it was observed that, there was no root-growth retardation in control, because, the root length increased from $5.7 \mathrm{~cm}$ to $7.2 \mathrm{~cm}$ after the period of the experiment.

Aberrations are among the noticeable effects of the effluent action on the root of $A$. cepa. The number of dividing cells and Mitotic Index (MI) in $A$. cepa exposed to different concentrations of textile and dyeing effluents were shown in Table 3. The results revealed that, there is dependency of cell division in $A$. cepa on concentrations of the effluents used. Thus, increase in concentrations of the treatments (the effluents) caused decrease in number of dividing cells, or in other words, less dividing cells were observed at higher concentration of the treatment than at lower concentrations, and more dividing cells were observed in control than in the treated $A$. cepa roots (Table 3 ).

Mitotic Index (MI) was also concentration dependent. There was decrease in MI with increase in concentration of the treatment on the test materials (the $A$. cepa roots) across both sites (Table 4). 
Special Conference Edition, November, 2019

Generally, MI lower than the control according to Fernandes et al. (2007) is an indication of alteration or interference derived from chemical action in growth and development of exposed organism, where as MI higher than control is the consequence of increased or uncontrolled cell division that may lead to disordered cellproliferation which results to cancerous cells or tumour tissues in an exposed organism (Hoshina, 2002).

The results of this study showed lower MI than the control at each concentration of the treatment. In Site 1 (E1), there was $22.67 \%$, $17.67 \%, 13.33 \%$ and $7.00 \%$ MI for $25 \% 50 \%$, $75 \%$, and $100 \%$ concentrations respectively. These values are all lower than $38.38 \%$ MI of the control (Table 3). The highest MI was $23.33 \%$ in $25 \%$ concentration of Site 2 (E2), while the lowest MI was $5.00 \%$ in $100 \%$ concentration of the same site. These values were also lower than $38.33 \%$ MI of the control, and hence this according to Fernandes et al. (2007) indicates the interference of the action of effluent concentration on the ability of the cell to divide which directly affects or interferes with growth and development of $A$. cepa roots under study.

Moreover, different structural aberrations were observed in $A$. cepa root exposed to different concentrations of textile and dyeing effluents at various sites (Table 4). Chromosomal bridge and incomplete cytokinesis are the most common aberrations observed in all sites. It was observed that percentage aberrations are inversely proportional to the concentration, thus less number of aberrant cells were observed at highest concentration (100\%) at both sites. This may be as a result of root decay observed at high concentrations of the effluents, and may be due to the toxicity effect of the effluent at high

\section{REFERENCES}

Abu, N.E. and Ezeugwu, S.C. (2008). Risk Evaluation of Industrial Wastewater on Plants Using Onion (Allium cepa L.) Chromosome Aberration Assay, Journal of Tropical Agriculture, Food, Environment and Extension, 7(3):242248.

Akan, J.C., Abdulrahman, F. I., Ayodele, J. T. and Ogugbuaja, V.O. (2007). Impact of Textile and Tannary Effluents on the Chemical Characteristics of Challawa River, Kano, Nigeria. International Journal of Basic and Applied Sciences 3(3): 1933-1947.

Ali, N.A., Ahmed, S. and Khan, A. (2008). Decolourization of Structurally Different Textile Dyes by Aspergillus concentration which leads to reduced mitotic activities at higher concentrations.

The effective concentrations that caused $50 \%$ effect on $A$. cepa roots $\left(\mathrm{EC}_{50}\right)$ for E1and $\mathrm{E} 2$ was $95 \%$, while it was $100 \%$ in E3. This showed that $95 \%$ was the concentration capable of causing effect to $50 \%$ experimental material ( $A$. cepa) but $100 \%$ in E3. According to Odeigah et al. (1997), the higher the $\mathrm{EC}_{50}$, the less toxic are the effluent samples. On the other hand, the regression coefficient $\left(R^{2}\right)$ was $0.8881,0.9776$ and 0.4361 for E1, E2 and E3 respectively, where $\mathrm{R}$ equals to $0.94,0.99$ and 0.66 implying that $94 \%, 99 \%$ and $66 \%$ of the total effects observed on $A$. cepa was as a result or associated with the treatment (the effluents) for the three sites respectively.

Statistical analysis (ANOVA) showed that, there is significant difference $(P<0.05)$ in the root growth of $A$. cepa exposed to different concentrations of effluents in ATM (E1) and $\mathrm{K} /$ Naisa (E2) sites. Tukey post-hoc analysis revealed that, the difference exists between the pair mean of $25-50 \%, 25-75 \%$ and $25-100 \%$ concentrations in $\mathrm{E} 1$, while the difference exists between the pair mean of $25-75 \%$ and $50-100 \%$ concentrations in E2, but no significant difference exists in root growth of $A$. cepa exposed to $\mathrm{K} / \mathrm{mata}$ (E3) effluents.

\section{CONCLUSION}

Although, textile and dyeing activities are promoting phenomenon for economic growth in Kano metropolis, their effluents should be effectively managed before discharge. This is because, the results of some heavy metals analysis as well as toxicity test showed that there was anomaly in the effective management of the effluents discharged and that poses negative effects on aquatic biota.

niger, World Journal of Microbiology and Biotechnology 22:89-93.

APHA (2005): Standard Methods for the Examination of Water and Wastewater. 21st Ed. American Public Health Association, Washington DC, Pp1220.

Aslam, M.M., Baig, M.A., Hassain, I., Qazi, I.A., Malik, M. and Saeed, H. (2004). Textile Wastewater Characterization and Reduction of its COD and BOD by Oxidation., Electronic Journal of Environment, Agricultural and Food Chemistry, 3(6): 804-11.

ATSDR, (2005). Agency for Toxic Substances and Disease Registry. Tox FAQS Chemical Fact Sheets, 
Special Conference Edition, November, 2019

Bakare, A.A., Mosuro, A. and Osibanjo, O. (2000). Effect of Simulated Leachate on Chromosomes and Mitosis in Roots of Allium cepa (L). Journal of Environmental Biology 21(3): 263 271.

Bremner, I. (1998). Manifestations of Copper Excess. American Journal of Clinical Nutrition, 67:1069S-1073S.

Chan, Y.K., Wong, C.K., Hsieh, P.H., Lau, T.K. and Wong, P.K. (2003). Application of Toxicity, Identification and Evaluation for a Sample of Effluents Discharged from Dyeing Factory in Hong Kong, Envirom. Toxicol., 18:312-316.

Dash, S., Panda, K.K. and Pand, B.B. (1988). Biomonitoring of Low Levels of Mercurial Derivatives in Water and Soil by Allium Micronucleus Assay. Mutation Residence, 203:11-21.

Deepali, K. and Gangwar, K. (2010). Metal Concentration in Textile and Tennary Effluents Associated Soils and Groundwater, New York Science Journal, 3(4):82-89.

Devis, L. and Ford, P. (1992). Toxicology Reduction and Control. Technomic Publishing Compony, Inc. Pp 231-245.

Dubey, S.K., Yadav, R., Chaturvedi, R.K., Yadav, R.K. and Minhas, P.S.( 2003). Spatial Changes in Ground Water Quality as a Result of Land Disposal of Sewage Effluent: A Case Study, International Conference on "Water Quality Management, 5:13-15 New Delhi, India.

FEPA (2002): Federal Environmental Protection Agency Act/ General Environmental Standard for Discharge of Effluents (Textiles/Dyestuffs and Dye Intermediate) Available at; $h t t p: / / w w w . f e p a . g o v$.

Fernandes, T.C. Mazzeo, D.E.C., Marin-Morales, M.A. (2007). Mechanism of Micronuclei Formation in Polyploidizated cells of Allium cepa Exposed to Trifluralin Herbicide, Pest. Biochem. Physiol. 88:252-259.

Fiskesjo, G. (1985). Allium Test on River Water from Bran and Sexan Before and After Closure of a Chemical Factory. Ambiologia, 14:99-103.

Fiskesjo, G. (1993). Allium Test In: Wastewater Monitoring, Environ. Toxicol. Water Qualty 8:291-298.

Fiskesjo, G. (1997): Allium Test for Screening Chemicals: Evaluation of Cytological Parameters. In: Olorunfemi, D.I., Ogiesere, U.M. and Akinboro, A.
(2011). Genotoxicity Screening of Industrial Effluents Using Onion Bulbs (Allium cepa), Journal of Applied Science and Environmental Management, 15(1):211-216.

Grant, W.F. (1982). Chromosome aberration assay in Allium. A report of the U.S.EPA Gene Tox. Program, Mutation Residence, 426:183-188.

Grover, I.S and Kaur (1999). Genotoxicity of Wastewater Samples from Sewage and Industrial Effluents Detected by Allium cepa Root Anaphase Aberration and Micronucleus Assay, Mutation Research, 426:183-188.

Hoshina, M.M. (2002). Avaliac, a o da possı 'vel contaminac,a a das a'guas do Ribeira o Claro - municl'pio de Rio Claro, pertencente a' bacia do rio Corumbataı', por meio de testes de mutagenicidade em Allium cepa, Trabalho de conclusa o (Bacharel e Licenciatura - Cie^ncias Biolo' gicas), Universidade Estadual Paulista, Rio Claro/SP, 52 p. In: Daniela, M. L., Maria, A. and Marin, M. (2009). Allium cepa Test in Environmental Monitoring: A Review of Its Application: Mutation Research/Reviews in Mutation Research, Elsevier 1-11. doi:10.1016/j.mrrev.2009.06.002.

Lah, B., Gurjane, G., Nekrep, F.V and MarinsekLoger, R. (2004). Comet Assay of Wastewater Genotoxicity Using Yeast's Cells. Bull Environmental Contamination Toxicology, 72:607616.

Maiti, S.K. (2004). Handbook of Methods in Environmental Studies, (Vol. 1 Water and Wastewater Analysis), 2nd Edn. ABD Publishers, B-46, Natraj, Imliwala Phatak, Jaipur-302 015 (Rajasthan) India Pp 1-279.

Matcalf and Eddy (2003). Wastewater Engineering, Treatment and Reuse. In: Asghari, A. H., Bina, B. and Movahedian, H. (2005): Toxicity Evaluation of Waste Water Treatment Plant Effluents Using Daphnia magna. Iranian Journal of Health Science Engineering, 2(2): 1-4.

Mc Mullan, G., Meehan, C., Conneely, A., Kirby, N., Robinson, T., Nigam, P., Banat, I., Marchant, R. and Smyth, W. (2007). Decolourization of Acid Orange by Bacteria of Different Tinctorial Type: A Comparative Study, World Journal of Microbiology and Biotechnology, 23:417-422. 
Special Conference Edition, November, 2019

Odeigah, P.G.C., Nuraddeen, O. and Amund, O.O. (1997). Genotoxicity of Oil Field Wastewater in Nigeria. Hereditas 126:161-167.

Olurunfemi, D.I., Ogeiseri, U.M., and Akinboro, A. (2011). Genotoxicity Screening of Industrial Effluents Using Onion bulbs (Allium cepa L.), Journal of Science, Environment and Management 15(1):211-216.

Olusegun, B.S., Fidelia, I.O. and Peter, G.C.O. (2010): Cytogenotoxicity Evaluation of Two Industrial Effluents Using Allium cepa Assay, African Journal of Env. Sci. and Tech., 4(1):021-027.

Rank, J. and Nielsen, M.H. (1993): A Modified Allium Test as a Tool in Screening of Genotoxicity of Complex Mixtures , Hereditas, 118:49-53.

Rank, J. and Nielsen, M.H. (1998): Genotoxicity Testing of Wastewater Sludge Using the Allium cepa Anaphase-Telophase Chromosome Aberration Assays, Mutation Research, 4(8):113-119.

Ratna and Padhi, B.S. (2012). Pollution due to Synthetic Dyes Toxicity and Carcinogenicity Studies and Remediation. International Journal of Environmental Science, 3(3):940-955.

Rindle, E. and Troll, W.J. (1975). Metabolic Reduction of Benzidine Azo Dyes Benzidine in the Rhesus Monkey. Journal of National Cancer Institute, 55:181-187.

Sharma, C.B.S. (1983): Plant Meristems as a Monitor of Genetic Toxicity of
Environmental Chemicals. Current Science 52:100-102.

Smaka-kinel, V., Stegnar, P., Lovka, M. and Toman, J. (1996). the Evaluation of Waste, Surface and Ground Water Quality Using the Allium Test Procedure, Mutation Residence, 368:171-179.

Smolder, R., Bervoets, L. and Blust, R. (2004). In-situ and Laboratory Bioassays to Evaluate the Impact of Effluents Discharges on Receiving Aquatic Ecosystems. Environmental Pollution, 132(2):231-243.

True, C.J. and Hayward, A.A. (1990). Relationship Between Microtox Text Results, Extraction Methods, Physical and Chemical Compositions of Marine Sediment Samples. Toxic Assess, 5:2946.

Ugoji, E.O. and Aboaba, O.O. (2004). Biological Treatments of Textile Industrial Effluents in Lagos Metropolis, Nigeria. Journal of Environment and Biol.. 25(4): 497-02.

Weber, E.J. and Adams, R.L. (1995): Chemical and Sediment Mediated Reduction of the Azo Dye Disperse Blue 79. Environmental Science and Technology. 29:1163-1170.

Yusuff, R.O. and Sonibare, J.A. (2004). Characterization of Textile Industries Effluents in Kaduna, Nigeria and Pollution Implications, Global Nest: The International Journal, 6 (3): 21120. 